\title{
TELAAH KONSEPTUAL RELATIONSHIP MARKETING DAN PERKEMBANGANNYA
}

\author{
Febrian Humaidi Sukmana $^{1}$, Sri Maryanti ${ }^{2}$ \\ ${ }^{1}$ Sekolah Tinggi Ilmu Ekonomi 45 Mataram, febrian.h.sukmana@gmail.com \\ ${ }^{2}$ Sekolah Tinggi Ilmu Ekonomi 45 Mataram, maryanti.sri88@gmail.com
}

\begin{abstract}
ABSTRAK
Banyak akademisi dan praktisi bidang pemasaran mengakui bahwa Relationship Marketing (RM) telah berkembang sangat pesat serta dianggap telah memberikan perubahan paradigma bahkan menjadi dasar pembentukan ulang teori pada bidang ilmu pemasaran dan topik RM ini menarik untuk dibahas. Kajian ini dimaksudkan untuk mensintesis berbagai pendapat dan hasil penelitian terdahulu agar dapat memberi gambaran kepada para akademisi, manajer, maupun dari kalangan pembaca umum mengenai apa dan bagaimana konsep RM. Berbagai sumber kepustakaan, baik berupa jurnal berkala, makalah konferensi dan buku teks, dikumpulkan dan digunakan sebagai acuan dalam monografi ini. Ada beberapa sudut pandang yang digunakan oleh para ilmuwan untuk menguraikan konsep RM, mulai dari aspek filosofi pemasaran, persepsktif berbasis sumber daya, strategi pemasaran, penciptaan nilai (value creation), dan penciptaan nilai bersama (value co-creation). Kesimpulan yang diperoleh dari berbagai sudut pandang yang digunakan dalam memformulasikan RM merupakan penguat bagi sudut pandang yang lain. Walaupun terlihat saling tumpang tindih, namun ada benang merah yang menghubungkan setiap gagasan. Secara teoritis bahwa penciptaan nilai bersama (value co-creation) merupakan perspektif yang paling relevan untuk menguraikan proses dan aktivitas RM pada era sekarang ini, sedangkan dalam praktiknya banyak perusahaan menempatkan RM sebagai salah satu strategi utama dalam kegiatan pemasaran perusahaan.
\end{abstract}

Kata Kunci: Relationship marketing, filosofi pemasaran, berbasis sumber daya, strategi pemasaran, penciptaan nilai, value co-creation.

\begin{abstract}
Many academics and practician of marketing admit that Relationship Marketing (RM) has developed vastly and also considered contributed to paradigm reformation, it even become the basis of marketing science theory reform. Hence, discussion on RM is interesting to be studied. The study aimed to synthesize various opinion and former research result to get a clearer view for academics, manager and general reader concerning concept of RM. Various literatures, either periodic journals, conference articles and textbooks are collected and used as references in this monography. Writer find out some perspectives used by scientists to describe RM concept, start from marketing philosopny aspect, resources based perspective, marketing strategy, value creation and mutual value creation (value co-creation). Writer concluded that various perspectives applied in formulating RM is strengthen the other perspective. Despite seems to be overlapped but there's a link that connected each perspective. Writer thought that (theoretically) value co-creation is the most relevant perspective to outlines RM process and activities in today's situation. Whereas in field, many corporates placed RM as one of their main strategy in marketed the company.
\end{abstract}

Keywords: relationship marketing, marketing philosophy, resources based, marketing strategy, value creation, value co-creation 


\section{PENDAHULUAN}

Kemunculan istilah relationship marketing (RM) sebagaimana disebutkan oleh Petrof (1997), mulai dikenal sejak 1983 yang dipelopori oleh Leonard L. Berry. Pada tahun itulah sebuah makalah berjudul "Relationship Marketing" dipresentasikan di American Marketing Association's Services Marketing Conference, dan untuk pertama kalinya istilah tersebut muncul dalam literatur pemasaran (lihat Berry, 2002). Namun menurut Blois (1996) dan Grönroos (1997), cikal bakal perspektif yang selanjutnya dikenal dengan istilah RM ini dirintis sejak tahun 1960an, ini bisa ditelusuri dari berbagai hasil penelitian yang dilakukan di Universitas Uppsala (Sulhaini, 2014). Adapun Christopher, Payne, \& Ballantyne (1993) telah menguraikan beberapa fase dari perkembangan fokus pemasaran dari transaction marketing menuju relationship marketing. Dimulai dari 1950an merupakan masa pemasaran konsumen dan implementasi konsep yang digunakan lebih ditekankan pada perusahaan manufaktur. Tahun 1960an merupakan masa pemasaran industri, sedangkan tahun 1970an perhatian lebih diarahkan pada sektor non publik, dan tahun 1980an merupakan era dimana sektor jasa menjadi fokus utama (lihat juga Palmatier, 2008). Setiap penelitian yang dilakukan pada masingmasing fase tersebut telah memberikan ide-ide baru dan berkontribusi bagi kelahiran paradigma RM (Christopher et al., 1993; Foster, 2008). Oleh sebab itu pada awal tahun 1990an, banyak penelitian telah mengindikasikan adanya pergeseran fokus dari pendekatan transaksional ke pendekatan relasional menuju pembangunan hubungan (Grönroos, 1994; Morgan \& Hunt, 1994; Sheth \& Parvatiyar, 1995).

Sebagaimana telah diuraikan secara ringkas di atas, RM yang selanjutnya secara teknis berkembang menjadi manajemen hubungan pelanggan (Customer Relationship Management-CRM) telah mengambil posisi sentral dalam strategi pemasaran dalam beberapa dekade terakhir. Serangkaian fenomena baru, termasuk transisi ke ekonomi berbasis layanan; kemajuan teknologi komunikasi, logistik, dan komputasi, meningkatnya persaingan global, dan komoditas produk yang mengalir lebih cepat telah meningkatkan arti penting "kesetiaan berbasis hubungan" (Palmatier, 2008). Selain itu, beberapa tren ini secara simultan meningkatkan keinginan pelanggan akan karakteristik unik yang ditemukan pada pertukaran berbasis hubungan (misalnya, pengurangan risiko yang dirasakan, kepercayaan yang lebih tinggi, kerjasama yang lebih baik, dan fleksibilitas yang lebih besar). Dengan demikian, dalam banyak situasi, baik penjual maupun pelanggan menjadi lebih tertarik untuk melakukan transaksi bisnis yang mengedepankan hubungan yang menguntungkan bagi semua pihak. Untuk mengetahui apa saja upaya yang dapat dilakukan sehingga hubungan yang menguntungkan dapat diwujudkan, penting untuk mendapatkan pemahaman yang baik tentang konsep dasar yang digunakan dalam pemasaran hubungan (RM). Sebagai langkah awal, kami akan menjelaskan bagaimana tulisan ini disusun (dengan menguraikan secara ringkas metode yang diigunakan), selanjutnya menyajikan pengantar untuk pendalaman konsep, yang nantinya akan dijadikan jembatan untuk memasuki topik utama yaitu penjabaran berbagai sudut pandang RM. Pada bagian akhir kami memberikan kesimpulan terkait topik yang dikaji. Topik ini mungkin sangat menarik bagi beberapa kalangan (misalnya akademisi dan praktisi pemasaran) yang menginginkan pemahaman yang memadai terkait konsep pemasaran hubungan (RM). Alasan inilah yang menjadi motivasi awal sekaligus tema sentral dalam tulisan ini. 


\section{TINJAUAN LITERATUR}

Terlepas dari perdebatan awal kemunculan RM sebagai sebuah konsep yang selanjutnya mendapat perhatian luas dari berbagai elemen (khususnya para penggiat pemasaran), namun belakangan praktisi dan akademisi telah bersepakat bahwa RM muncul sebagai perspektif baru dan berkembang pesat serta dianggap telah memberikan perubahan paradigma bahkan menjadi dasar pembentukan ulang teori pada bidang ilmu pemasaran (Berry, 2002; Egan, 2011; Grönroos, 1994, 1996, 2000; Gummesson, 2008; Kotler \& Keller, 2016; Morgan \& Hunt, 1999, 1994; Petrof, 1997; Sheth \& Parvatiyar, 1992). Konsep ini dianggap sebagai reinkarnasi dari praktik pemasaran di masa pra industri dimana produsen dan konsumen berinteraksi secara langsung dan menumbuhkan ikatan yang bersifat rasional, fungsional, emosional dan struktural dalam aktivitas bisnis (Sheth \& Parvatiyar, 1995; Sulhaini, 2014). Dengan kata lain, perubahan yang terjadi adalah pergeseran paradigma pemasaran yang sebelumnya berorientasi mass marketing menjadi individualized marketing, atau kegiatan yang sebelumnya berfokus pada mendapatkan pelanggan sebanyak-banyaknya ke arah mempertahankan serta membangun suatu hubungan bersama pelanggan yang bernilai stategis (Rashid, 2003).

Perkembangan selanjutnya, konsep dan kerangka kerja RM mulai berfokus untuk menjelaskan arti penting hubungan antara produsen, mitra dan konsumen dalam suatu aktivitas bisnis yang dilakukan oleh seluruh stakeholder (Sharma, Tzokas, Saren, \& Kyziridis, 1999). Senada dengan itu Morgan \& Hunt (1994) juga menjelaskan, bagi perusahaan, pertukaran relasional dapat terjadi dengan pemasok barang, pemasok jasa, unit bisnis, karyawan, departemen fungsional, pelanggan perantara, pelanggan utama, pesaing, organisasi nirlaba, dan pemerintah. RM bertujuan untuk mengidentifikasi, membangun, memelihara, meningkatkan dan bila perlu mengakhiri hubungan dengan pelanggan dan pemangku kepentingan lainnya (Grönroos, 1994). Lebih lanjut, Grönroos (1994) menambahkan, tujuan lainnya adalah untuk mempertahankan dan meningkatkan profitabilitas perusahaan, sekaligus memenuhi tujuan semua pihak dengan saling tukar dan memenuhi janji. Madhavaram, Arnett, \& Hunt (2006) juga mencatat beberapa faktor yang menyebabkan teori ini berkembang pesat, ini dikarenakan adanya kecenderungan di negara-negara maju untuk lebih berorientasi pada layanan, perkembangan dan adopsi teknologi informasi yang begitu masif, globalisasi, serta daya tarik relung pasar.

Namun disisi lain, Palmatier (2008) mengingatkan para pemasar (perusahaan), bahwa faktor dengan dampak paling signifikan terhadap kualitas hubungan pelanggan adalah konflik yang belum terselesaikan. Penelitian yang ada dengan jelas menunjukkan bahwa konflik antara penjual dan pelanggan dapat dengan cepat merusak dan menghancurkan kepercayaan, komitmen, dan pada akhirnya sebuah hubungan yang dibangun melalui investasi bertahun-tahun hilang begitu saja (Palmatier, 2008). Untuk menghindari dan mengurangi konflik tersebut, perusahaan harus memastikan bahwa proses bisnis mereka selaras dengan strategi pemasaran hubungan mereka. Budaya perusahaan harus menekankan pentingnya menyelesaikan konflik, dan harus menerapkan sistem formal untuk memperbaiki masalah pelanggan (Palmatier, 2008; Palmatier, Jarvis, Bechkoff, \& Kardes, 2009; Zhang, Watson, Palmatier, \& Dant, 2016).

Untuk melangkah lebih jauh dalam memahami apa dan bagaimana membangun hubungan yang menguntungkan, penting kiranya untuk mengetahui apa saja pemikiran yang telah dikemukakan para ilmuan pemasaran terkait topik ini. Sulhaini (2014) telah mengklasifikasikan beberapa sudut pandang yang digunakan oleh para ilmuwan pemasaran dalam mendefinisikan RM, antara lain: filosofi pemasaran (Gronroos, 1990; 
Palmer, 1995; Palmer \& Koenig-Lewis, 2009; Takala \& Uusitalo, 1996), berbasis sumber daya (Morgan \& Hunt, 1999; Srivastava, Shervani, \& Fahey, 1998), strategi pemasaran (Morgan \& Hunt, 1994; Sheth \& Parvatiyar, 1992), proses penciptaan nilai (Grönroos, 1997; Ravald \& Grönroos, 1996; Smirnova \& Kushch, 2006; Wehrli \& Jüttner, 1994), bahkan sudut pandang nilai telah dikaji lebih mendalam sehingga menghasilkan sudut pandang baru yang dikenal sebagai value co-creation process (Bröring \& Cloutier, 2008; Carbonell, Rodríguez-Escudero, \& Pujari, 2009; Erdélyi, Ngugi, \& Johnsen, 2010; Forsström, 2005; Prahalad \& Ramaswamy, 2004; Qi, Wang, Wang, \& Zhang, 2010; Ramaswamy, 2008; Ritter \& Gemuenden, 2003; Vargo \& Lusch, 2010). Beberapa sudut pandang yang telah diklasifikasikan oleh Sulhaini tersebut akan coba dijabarkan sehingga terlihat bagaimana pendapat-pendapat tersebut dapat merepresentasikan sudut pandang yang digunakan sebagai konstruksi awal dalam membangun konsep RM.

\section{METODE}

Monografi ini berupaya untuk mensintesis berbagai pendapat dan hasil penelitian sebelumnya yang dikemukakan oleh para ilmuwan bidang pemasaran untuk memberikan suatu uraian ringkas namun padat kepada para akademisi dan praktisi pemasaran, mengenai apa dan bagaimana konsep relationship marketing. Berbagai sumber kepustakaan, baik berupa jurnal berkala, makalah konferensi dan buku teks, dikumpulkan dan digunakan sebagai sumber acuan dalam monografi ini. Tidak kurang dari 59 sumber bacaan yang kami gunakan dalam monografi ini. Rentang waktu publikasi (baik berupa artikel jurnal berkala, malakah konfrensi dan buku teks) yang digunakan sebagai sumber utama dalam monografi ini: paling lama adalah artikel terbitan tahun 1987 yang disusun oleh Dwyer, Schurr, \& Oh dengan judul "Developing Buyer-Seller Relationships" dan diterbitkan di Journal of Marketing. Adapun dua sumber kepustakaan terakhir (yang paling relevan dengan topik yang dibahas) berasal dari Grönroos (2017) yang dipublikasikan di Journal of Global Scholars of Marketing Science dengan judul "Relationship Marketing and Service: An update" dan sebuah buku yang berjudul "Customer Engagement Marketing" yang disusun oleh Palmatier, Kumar, \& Harmeling (sebagai Editor), diterbitan pada tahun 2018 oleh Palgrave Macmillan. Dengan kata lain, sumber kepustakaan yang digunakan dalam monografi ini memiliki rentang waktu penerbitan mulai dari tahun 1987 sampai dengan 2018 (kurang lebih 30 tahun). Waktu yang sangat panjang tersebut dapat menggambarkan bagaimana konsep RM berkembang sedemikian rupa sehingga catatan-catatan dari berbagai sumber kepustakaan yang digunakan akan memberikan suatu informasi yang sangat berguna dalam penyajian monografi ini. Jika sumber kepustakaan yang digunakan dalam monografi ini diklasifikasi berdasarkan tahun penerbitan (misalnya: di bawah tahun 2000; 2000 sampai 2010; dan 2010 ke atas) maka akan didapat klasifikasi sebagai berikut: di bawah tahun 2000 ada 21 sumber bacaan yang digunakan. Pada rentang tahun 2000 sampai dengan 2010, sekitar 26 literatur digunakan sebagai rujukan. Adapun untuk sumber rujukan yang digunakan pada rentang tahun 2010 sampai dengan 2018, tidak kurang dari 12 sumber bacaan yang terdiri dari artikel jurnal dan buku teks.

Selanjutnya, sistematika yang kami gunakan dalam penyajian monografi ini dapat diuraikan sebagai berikut. Pada tahap awal, kami coba membahas beberapa konsep dasar mengenai RM, dimulai dari uraian sejarah kemunculan pemikiran pemasaran yang mengarah pada aspek layanan dan hubungan, selanjutnya uraian tentang perkem- 
bangannya, sampai pada penjabaran sudut pandang yang digunakan sebagai pijakan dalam membangun konsep RM.

\section{PEMBAHASAN}

\section{Filosofi Pemasaran}

Untuk memahami pengertian RM, terlebih dahulu perlu diketahui perbedaan konsep ini dengan paradigma transaction yang sebelumnya banyak dianut oleh para akademisi dan praktisi bidang pemasaran. Hunt (2010) menjelaskan perbedaan tersebut yang pada prinsipnya bahwa pertukaran dalam bentuk transaksi adalah bentuk pertukaran yang terjadinya pada waktu yang sangat singkat dan tidak mempunyai dampak untuk hubungan yang berkelanjutan. Sedangkan dalam pemasaran hubungan, aspek penting yang perlu mendapat perhatian adalah bagaimana hubungan penjual-pembeli selalu selaras dan berkelanjutan. Jadi, segala aktivitas baik itu sebelum, pada saat, dan setelah terjadinya pertukaran, perhatian tetap diarahkan kepada hubungan ini (Grönroos, 1994, 1997, 2000; Hunt, 2010; Madhavaram et al., 2006; Morgan \& Hunt, 1999, 1994; Palmatier et al., 2009; Ravald \& Grönroos, 1996). Dengan kata lain, perbedaan antara transaksi dan pemasaran hubungan antara lain dapat ditinjau dari tenggang waktu terjadinya hubungan, keterlibatan pelaku, harapan-harapan yang timbul dari hubungan tersebut, kerjasama yang mungkin terjadi, antisipasi untuk kelanjutan hubungan, antisipasi tentang terjadi konflik dan kepentingan pribadi, serta penting-tidaknya kepercayaan (trust) dalam hubungan (Dwyer et al., 1987).

Konsep RM sejalan dengan filosofi marketing concept yang dikemukakan oleh Kotler \& Armstrong (2018) dan Kotler \& Keller (2016), bahwa fokus dari suatu organisasi/bisnis adalah kebutuhan dan keinginan konsumen (customer's need and wants), dan dengan menggunakan integrasi dari bauran pemasaran maupun integrasi semua fungsi yang ada dalam organisasi maka diharapkan tercapainya kepuasaan konsumen sebagai tujuan dan janji perusahaan (organisasi). Perubahan besar dalam filosofi bisnis mungkin diperlukan jika RM benar-benar diadopsi. Jika tidak, perusahaan mungkin hanya membayar "lip-service" ke filosofi baru ini (Grönroos, 2017). Menggunakan teknik pemasaran langsung dan mengembangkan kemitraan saja tidaklah cukup, RM membutuhkan lebih dari itu, demikianlah yang dikemukakan oleh Grönroos (2008, 2017). Takala \& Uusitalo dalam artikelnya menawarkan kerangka kerja untuk analisis etis mengenai masalah RM, yang pada akhirnya akan menghasilkan bentuk solusi konsturktif. Mereka menjelaskan bahwa, analisis hubungan pemasaran dapat dilihat dari sudut pandang teori etika. Beberapa teori yang digunakan adalah deontologi, utilitarianisme, etika kebajikan, dan emotivisme. Kerangka kerja tersebut akan membantu membuat praktik RM secara etis lebih tahan lama dan, dengan cara ini membuat praktik pemasaran yang dijalankan akan lebih kompetitif dan menguntungkan (Takala \& Uusitalo, 1996). Disisi lain Palmer (1995) mengingatkan dalam pengembangan program RM (yang diklaim sebagai paradigma baru dalam suatu aktivitas pemasaran) untuk tidak mengabaikan adanya pertukaran relasional sebagai bentuk pertukaran yang dominan dibanyak ekonomi dunia. Ia juga menyarankan kehati-hatian dalam pelaksanaan aktivitas pemasaran hubungan taktis gaya barat di pasar dimana hubungan mewakili nilai budaya inti (terutama sekali dalam konteks lintas budaya). Artinya, apa yang menjadi penekanan Palmer (1995) pada pemahaman nilai budaya inti dari suatu pasar, senada dengan apa yang dikemukakan oleh Takala \& Uusitalo (1996), mereka menekankan 
aspek etis (sifat moral) dari suatu bisnis yang pada akhirnya akan menghasilkan suatu hubungan yang menguntungkan bagi semua pihak.

\section{Berbasis Sumber Daya}

Salah satu fokus dari banyak penelitian tentang RM berpusat pada dua isu utama, yaitu: apa manfaat adopsi pemasaran hubungan? Dan, bagaimana hubungan pemasaran dibangun dan dipelihara? (lihat Morgan \& Hunt, 1999). Lebih lanjut, Morgan \& Hunt berpendapat bahwa pemasaran hubungan hanya boleh diadopsi bila menawarkan atau memberi kontribusi, keunggulan kompetitif pada perusahaan secara keberlanjutan. Morgan \& Hunt (1999) menyarankan, langkah awal yang digunakan untuk lebih memahami peran strategis pemasaran hubungan adalah mengadopsi pendekatan berbasis sumber daya. Hal pertama yang harus dilakukan yaitu mengklarifikasi peran yang diperoleh sumber daya melalui hubungan dalam suatu aktivitas RM, lalu mengisolasi dan membahas berbagai jenis sumber daya yang bisa didapat melalui hubungan tersebut. Akhirnya, mengembangkan beberapa proposisi untuk menilai nilai strategis dari sumber daya tersebut dalam suatu hubungan pemasaran (Morgan \& Hunt, 1999).

Sumber daya berwujud dan tidak berwujud membentuk aset fundamental yang memungkinkan perusahaan mengembangkan kemampuannya pada tingkat perusahaan (Srivastava et al., 1998). Dengan demikian, perusahaan berusaha untuk mengembangkan dan mempertahankan keunggulan komparatif dalam hal berbagai sumber daya (Morgan \& Hunt, 1999). Selanjutnya, sebagaimana diuraikan oleh Sacui \& Dumitru (2014), tujuan perusahaan adalah memberikan nilai bagi investor. Menurut teori pandangan berbasis sumber daya (lihat Sacui \& Dumitru, 2014), perusahaan perlu mengembangkan keunggulan diferensial untuk mempertahankan pendapatan melebihi biaya modal. Sumber daya yang berharga, langka, tidak ada bandingannya dan tidak dapat diganti, memungkinkan bisnis mengembangkan dan mempertahankan keunggulan kompetitif. Perusahaan dapat menciptakan keunggulan diferensial dengan membangun aset berbasis pasar. Tren yang muncul menunjukkan bahwa tujuan pemasaran adalah menciptakan dan mengelola aset berbasis pasar untuk memperoleh nilai pemegang saham dan konsumen potensialnya. Dalam kondisi seperti ini, sumber daya yang dialokasikan untuk strategi pemasaran harus dipandang sebagai investasi yang menciptakan asset (Sacui \& Dumitru, 2014).

Sebelumnya Palmatier (2008) telah menjelaskan hal senada, Ia menekankan peran penting masing-masing individu dalam perusahaan (khususnya karyawan) sebagai barisan terdepan untuk membangun dan memelihara hubungan pelanggan yang kuat. Dalam banyak kasus, investasi pemasaran hubungan perusahaan harusnya dapat lebih diprioritaskan untuk mempekerjakan, melatih, dan terus memotivasi karyawan sehingga dapat memberikan suatu kinerja pelayanan yang baik bagi pelanggan. Jika memungkinkan, perusahaan harus menyelaraskan karyawan yang berdedikasi dan kompeten kepada setiap pelanggan untuk memanfaatkan dampak kuat dari hubungan semacam itu. Pada saat yang sama, perusahaan harus menyadari bahwa loyalitas yang dihasilkan dari hubungan pelanggan dan penjual (karyawan), sering "dimiliki" oleh individual penjual itu sendiri dan dapat hilang jika tenaga penjual tersebut pindah ke perusahaan lain (Palmatier, 2008). Dengan demikian, perusahaan yang membangun loyalitas berbasis relasional harus menyeimbangkan manfaat dari hubungan karyawan dan pelanggan dengan strategi perputaran karyawan. 


\section{Strategi Pemasaran}

Relationship marketing telah mengambil posisi sentral dalam strategi pemasaran dalam beberapa dekade terakhir (Grönroos, 1996; Harmeling, Kumar, \& Palmatier, 2018; Palmatier, 2008; Palmatier et al., 2009, 2018; Zhang et al., 2016). Morgan \& Hunt (1994) mengajukan definisi RM sebagai seluruh kegiatan pemasaran yang diarahkan untuk membangun, mengembangkan dan mempertahankan hubungan pertukaran yang sukses. Hal ini sering diakui dalam teori pemasaran dan praktik bahwa, salah satu tujuan pemasaran hubungan yang paling penting adalah untuk memelihara hubungan jangka panjang dengan pelanggan (Palmatier et al., 2009). Berbagai penelitian yang telah dilakukan mengakui manfaat pemasaran hubungan karena dapat menghasilkan kinerja bisnis yang lebih baik yang mencakup peningkatan pertumbuhan penjualan dan keuntungan (Morgan \& Hunt, 1999; Sirdeshmukh, Singh, \& Sabol, 2002). Banyak bisnis beralih ke pemasaran hubungan untuk membangun hubungan yang kuat dengan kontak utama mereka untuk membedakan diri dari pesaing mereka (Sharafizad \& Standing, 2017).

Lebih jauh, Morgan \& Hunt $(1999,1994)$ mengingatkan bahwa pemasaran hubungan yang sukses membutuhkan komitmen dan kepercayaan hubungan. Komitmen umumnya didefinisikan sebagai mitra pertukaran yang percaya bahwa hubungan yang berkelanjutan dengan orang lain sangat penting untuk menjamin upaya maksimal dalam mempertahankannya (Morgan \& Hunt, 1999). Komitmen telah menjadi komponen kualitas hubungan yang paling sering diterima (Dwyer et al., 1987). Selanjutnya Dwyer et al. (1987) menjelaskan ada empat jenis hubungan antara pembeli dan penjual, yaitu hubungan bilateral, hubungan yang dipertahankan oleh penjual, hubungan yang dipertahankan oleh pembeli, pertukaran terpisah. Bagi perusahaan, pertukaran relasional dapat terjadi dengan pemasok barang, pemasok jasa, unit bisnis, karyawan, departemen fungsional, pelanggan perantara, pelanggan utama, pesaing, organisasi nirlaba, dan pemerintah (Morgan \& Hunt, 1994). Smith (2011) menyatakan bahwa kepercayaan, kepuasan dan komitmen menjadi dasar penilaian atas kualitas hubungan. Kualitas hubungan tersebut ditentukan oleh hubungan manajemen yang terdiri dari relationship investment, open communication dan relationalism. Kualitas hubungan dan hubungan manajemen secara bersamaan dipengaruhi oleh sebuah working relationship yang dihipotesakan sebagai faktor-faktor yang menentukan (determined) yaitu kesamaan (similarity) dari life stage, sex, culture, work attitudes dan personality (Smith, 1998).

Jika dilihat dari aspek strategi pemasaran perusahaan, investasi hubungan pemasaran harus dialokasikan terutama untuk program sosial dan struktural daripada program keuangan. Program sosial tampaknya menghasilkan tingkat pengembalian tertinggi. Program pemasaran hubungan ditujukan untuk meningkatkan komunikasi terkait jumlah, frekuensi, dan kualitas hubungan antara perusahaan yang diwakili oleh penjual (karyawan), dan strategi ini sangat efektif di awal siklus hidup, karena komunikasi adalah pendorong kuat kualitas hubungan dan pertumbuhan hubungan masa depan atau kecepatan relasional (Palmatier, 2008). Lebih lanjut Palmatier (2008) menjelaskan, program struktural seperti tatapmuka pemrosesan pesanan elektronik, kemasan yang disesuaikan, dan kebijakan lainnya atau perubahan prosedural, juga meningkatkan hubungan antara pelanggan dan perusahaan penjualan. Program RM yang terstruktur dan terintegrasi harus menargetkan pelanggan dengan volume tinggi, ada, atau berkembang, karena volume penjualan yang lebih besar mendukung biaya implementasi dan seringkali memberikan nilai lebih bagi pelanggan dengan interaksi frekuensi tinggi. Sebaliknya, perusahaan harus meminimalkan penggunaan proaktif dari program keuangan 
(misalnya, pengurangan harga atau diskon) dan sebaliknya menganggap program ini hanya sebagai tanggapan kompetitif untuk pesaing. Sebagian besar program keuangan tidak dapat memberikan hasil jangka pendek yang positif atau membangun loyalitas relasional jangka panjang (Palmatier, 2008; Palmatier et al., 2009, 2018).

Selaras dengan penjelasan di atas, Cravens \& Piercy (2012) menguraikan klasifikasi pola hubungan yang dapat dilakukan oleh perusahaan, antara lain: a) customersupplier relationships: hubungan pelanggan dan pemasok terjadi karena adanya berbagai tahapan dalam proses nilai tambah yang melibatkan pemasok, manufaktur, distributor, konsumen dan perusahaan yang menjadi pemakai akhir atas barang dan jasa dalam saluran distribusi vertikal; b) distribution channel relationships: hubungan yang terjadi antara produsen dan perantara (misalnya, distributor dan pengecer). Rantai nilai hubungan ini dimaksudkan untuk memberikan akses kepada produsen terhadap konsumen dan perusahaan pemakai akhir, dan c) end-user customer relationships: merupakan dorongan untuk melakukan strategi hubungan dengan pemakai akhir (end-users), dilakukan untuk mengurangi dampak perubahan lingkungan bisnis yang cepat melalui hubungan kemitraan. Tekait dengan strategi yang bisa dijalankan oleh perusahaan, Cravens \& Piercy (2012) menawarkan dua strategi utama yaitu: 1) strategi hubungan kooperatif, bertujuan untuk mendapatkan keunggulan kompetitif untuk meningkatkan permintaan atas akses teknologi, perluasan sumber daya, peningkatan produktivitas dan kualitas serta penetrasi pasar yang baru. Contoh strategi hubungan kooperatif adalah aliansi, joint-ventures, dan kolaborasi produsen-pemasok. 2) strategi hubungan kolaboratif, mencakup aktivitas yang membagi pengalaman seperti disain proses dan produk, program kerja sama pemasaran, asistensi program aplikasi, kontrak pasokan jangka panjang dan program JIT (Just in Time).

\section{Penciptaan Nilai (Value Creation)}

Konsep nilai merupakan dasar penyusun RM (Ravald \& Grönroos, 1996). Pemasaran dalam kontek relasional dapat dilihat sebagai suatu proses yang harus mendukung penciptaan nilai bagi konsumen (Grönroos, 1994, 1996, 1997, 2008, 2017). Hal ini dapat dijelaskan bahwa penciptaan nilai merupakan bagian penting dalam suatu interaksi, bukan hanya semata-mata pertukaran produk. Perusahaan yang sukses tidak berfokus pada diri mereka sendiri atau bahkan di industri yang mereka masuki, tetapi lebih berfokus pada sistem penciptaan nilai (Normann \& Ramírez, 1993). Strategi pemasaran yang didasarkan pada hubungan akan menentukan total nilai bagi konsumen, dengan kata lain, nilai didefinisikan dan dinikmati hanya oleh konsumen dan bukan berdasarkan evaluasi dari perusahaan sendiri terhadap penawaran totalnya (Sulhaini, 2014). Pendekatan yang digunakan dalam perspektif ini adalah bagaimana perusahaan menciptakan nilai tambah bagi konsumennya (Grönroos, 2008, 2017; Normann \& Ramírez, 1993; Prahalad \& Ramaswamy, 2004; Ravald \& Grönroos, 1996; Sacui \& Dumitru, 2014; Sirdeshmukh et al., 2002), karena nilai diciptakan dan dipersepsikan sepanjang hubungan perusahaan dan konsumen berlangsung (Grönroos, 1997, 2017). Sebagaimana dijelaskan lebih lanjut oleh (Grönroos, 2000) dialog hubungan adalah proses penalaran bersama-sama agar dua atau lebih pihak mengembangkan platform pengetahuan bersama. Pemasaran hubungan difasilitasi dengan syarat agar platform pengetahuan ini memungkinkan pemasok menciptakan nilai tambah bagi pelanggannya di atas nilai barang dan jasa yang dipertukarkan dalam hubungan tersebut. Untuk dialog hubungan yang muncul dalam proses yang sedang berjalan, efek komunikasi dari upaya komunikasi terencana serta interaksi produk dan layanan antara pemasok dan pelanggannya 
harus saling mendukung, dan disinilah nilai ekstra yang dibutuhkan dari hubungan itu tercipta (Grönroos, 2000).

Secara sederhana kita dapat mengatakan bahwa perusahaan berupaya menawarkan suatu nilai untuk konsumennya, namun konsumen sendiri yang akan menentukan penilaiannya atas suatu gambaran kepantasan dari sisi ekonomi, teknis, pelayanan, serta manfaat fungsional dan sosial yang diperoleh seorang konsumen pada harga yang dia bayarkan (Rich, 1999). Lebih lanjut, Grönroos (2008) menjelaskan perbedaan antara value-in-exchange dan value-in-use. Dalam makalahnya Grönroos menyimpulkan bahwa value-in-exchange pada intinya menyangkut sumber daya yang digunakan sebagai fondasi nilai yang ditujukan untuk memfasilitasi pemenuhan nilai konsumen dalam penggunaan. Saat menerima nilai dalam penggunaan sebagai konsep penciptaan nilai dasar pelanggan adalah pembuat nilai. Mengadopsi logika layanan memungkinkan perusahaan terlibat dalam proses penghasil nilai pelanggan mereka, dan penawaran pasar diperluas untuk mencakup interaksi pelanggan perusahaan. Dengan cara ini, pemasok bisa menjadi value co-creation dengan pelanggannya (Grönroos, 2017).

\section{Penciptaan Nilai Bersama (Value Co-creation)}

Dimana sebelumnya perusahaan dipandang sebagai pencipta nilai yang bersifat searah dan cenderung berorientasi transaksional, pada perkembangan selanjutnya terjadi pergeseran perspektif ke arah value co-creation (lihat Bhalla, 2011; Cambra-Fierro, Melero-Polo, \& Sese, 2018; Grönroos, 2008, 2017; Ramaswamy, 2008; Vargo \& Lusch, 2010). Senada dengan hal tersebut, Ramaswamy (2008) juga menjelaskan tentang terjadinya pergeseran fundamental dalam proses penciptaan nilai, yang sebelumnya hanya berorientasi pada nilai produk dan jasa yang ditawarkan menjadi experience cocreation. Istilah ini mengambarkan suatu proses penciptaan nilai bersama melalui interaksi kreatif di dalam sistem bisnis yang menghasilkan suatu pengalaman nilai, tidak saja bagi konsumen namun juga nilai strategis bagi perusahaan, sehingga kedua belah pihak mendapatkan manfaat dari interaksi yang dilakukan (Bhalla, 2011; Forsström, 2005; Ramaswamy, 2008; Ritter \& Gemuenden, 2003). Prahalad \& Ramaswamy (2004) mendefinisikan co-creation sebagai penciptaan nilai bersama oleh perusahaan dan pelanggan, yang memungkinkan pelanggan untuk menggabungkan pengalaman layanan sesuai dengan konteks mereka. Jadi, keterlibatan atau keikutsertaan konsumen dalam pengembangan produk maupun jasa memberikan suatu umpan balik bagi perusahaan untuk dapat memahami kebutuhan, keinginan dan perilaku konsumen (Carbonell et al., 2009; Erdélyi et al., 2010; Palmer \& Koenig-Lewis, 2009). Dengan kata lain, konsumen harus diperlakukan sebagai mitra jangka panjang dalam hubungan yang saling menguntungkan dari pada sasaran manipulatif atau disinformasi untuk keuntungan jangka pendek (Grönroos, 2008, 2017). Namun perlu dicatat, Bendapudi \& Leone (2003) menyimpulkan dalam sebuah makalah empiris mereka, bahwa asumsi penyesuaian untuk penciptaan dan produksi bersama dapat digunakan hanya jika pelanggan memiliki keahlian untuk membuat barang atau jasa sesuai dengan keinginannya.

Munculnya co-creation dapat dikaitkan dengan tiga isu berbeda seperti yang disarankan oleh OHern \& Rindfleisch (2010) yaitu: 1) asimetri informasi antara permintaan pelanggan dan kemampuan pabrikan; 2) pemberdayaan pelanggan; 3) munculnya dan meluasnya penerapan teknologi digital. Selanjutnya, O'hern dan Rindfleisch menguraikan dua langkah kunci penciptaan bersama yang berhasil, Pertama, kontribusi gagasan: perusahaan harus meyakinkan pelanggannya untuk menyampaikan gagasan 
mereka (yaitu berkontribusi). Namun, upaya ini sebenarnya cukup sulit karena sebagian besar pelanggan cukup sibuk dan tidak peduli dengan panggilan perusahaan. Jika pelanggan tidak mendapatkan insentif dengan cara yang menarik, mereka enggan untuk berpartisipasi dan memberi keuntungan kepada perusahaan. Akibatnya, sebagian besar usaha co-creation gagal karena mereka tidak mendapatkan banyak kiriman (baik berupa insentif atau bentuk lainnya). Kedua, memilih gagasan yang layak: setelah menerima kontribusi, perusahaan kemudian harus memilih gagasan mana yang paling menguntungkan, layak dan dapat diimplementasikan. Tantangan dari proses seleksi adalah bahwa sebagian besar gagasan yang diterima perusahaan mungkin tidak terlalu berguna, tidak praktis dan sulit diterapkan (OHern \& Rindfleisch, 2010).

Lebih lanjut dijelaskan oleh Grönroos (2017), dalam konteks pemasaran, pelayanan dan hubungan merupakan dua hal yang saling berkaitan. Pelayanan didasarkan pada hubungan antar aktor, maka dari itu pemasaran hubungan tidak dapat dilaksanakan tanpa pelayanan. Perkembangan logika layanan dalam berbagai literatur menekankan bahwa mengadopsi perspektif layanan pada bisnis dan pemasaran memungkinkan perusahaan jasa dan produsen produk dapat mengembangkan, memelihara dan meningkatkan hubungan dengan pelanggan. Dari sudut pandang pelanggan, semua perusahaan adalah perusahaan jasa. "promise theory" menunjukkan bahwa janji yang dibuat oleh penjualan dan upaya pemasaran konvensional harus berhasil dijaga. Jika tidak, pemasaran akan gagal. Kesimpulan dari perspektif value co-creation ini adalah membangun hubungan dengan konsumen untuk memberikan akses kepada perusahaan bagaimana ide atau gagasan penting dan unik yang diperoleh dari interaksinya dengan konsumen dapat meningkatkan daya saing dan inovasi perusahaan (Grönroos, 2017).

\section{KESIMPULAN}

Berbagai pergeseran yang terjadi saat ini termasuk transisi ke ekonomi berbasis layanan, kemajuan teknologi komunikasi, logistik, dan komputerisasi, meningkatnya persaingan global, dan komoditas produk yang mengalir lebih cepat telah meningkatkan arti penting "kesetiaan berbasis hubungan". Tren ini sekaligus meningkatkan kebutuhan dan keinginan konsumen atau pelanggan untuk mendapatkan karakteristik unik (berbasis hubungan) dari pertukaran yang mereka lakukan. Beberapa contoh karakteristik unik yang diharapkan oleh pelanggan antara lain, pengurangan risiko yang dirasakan, kepercayaan yang lebih tinggi, kerjasama yang lebih baik, dan fleksibilitas yang lebih besar. Maka dari itu penting bagi perusahaan untuk memberikan perhatian khusus pada aktivitas transaksi bisnis yang mengedepankan hubungan yang menguntungkan bagi semua pihak. Konsep RM dianggap sebagai reinkarnasi dari praktik pemasaran di masa pra industri dimana produsen dan konsumen berinteraksi secara langsung dan menumbuhkan ikatan yang bersifat rasional, fungsional, emosional dan struktural dalam aktivitas bisnis, artinya ada perubahan paradigma pemasaran yang sebelumnya berorientasi mass marketing menjadi individualized marketing. RM merupakan proses untuk mengidentifikasi, mengembangkan, memelihara, dan mengakhiri pertukaran relasional dengan tujuan meningkatkan kinerja dan profitabilitas perusahaan, sekaligus memenuhi tujuan semua pihak dengan saling tukar dan memenuhi janji. Tujuan akhir dari aktivitas ini adalah membangun dan mempertahankan suatu hubungan bersama yang bernilai stategis. Konsep ini menekankan pentingnya hubungan antara produsen, mitra dan konsumen dalam suatu aktivitas bisnis yang dilakukan oleh seluruh stakeholder. 
Salah satu faktor penting yang harus diperhatikan oleh pemasar atau perusahaan terkait dampak paling signifikan terhadap kualitas hubungan pelanggan adalah konflik yang belum terselesaikan. Beberapa penelitian menunjukkan bahwa konflik antara penjual dan pelanggan dapat dengan cepat merusak dan menghancurkan kepercayaan, komitmen, dan pada akhirnya, hubungan yang dibangun melalui investasi bertahuntahun dapat hilang begitu saja. Secara filosofis, proses dan aktivitas RM perlu memperhatikan aspek etika bisnis (moral) dan aspek nilai (budaya), sebelum masuk pada domain kebutuhan dan keinginan konsumen sasaran. Dilihat dari konteks sumber daya, sumber daya berwujud dan tidak berwujud membentuk aset fundamental yang memungkinkan perusahaan mengembangkan kemampuan terbaiknya, dengan demikian perusahaan akan mampu untuk mengembangkan dan mempertahankan keunggulan komparatif dalam hal berbagai sumber daya yang dimiliki. Menelusuri strategi pemasaran yang lazim dikembangkan saat ini, RM merupakan salah satu bentuk strategi yang sukses diterapkan oleh banyak perusahaan. Berbagai penelitian yang telah dilakukan mengakui manfaat RM karena dapat menghasilkan kinerja bisnis yang lebih baik yang mencakup peningkatan pertumbuhan penjualan dan keuntungan. Namun, perlu untuk dicatat, investasi pemasaran hubungan harus dialokasikan terutama untuk program sosial dan struktural daripada program keuangan. Beberapa penelitian mensinyalir bahwa program sosial tampaknya menghasilkan tingkat pengembalian tertinggi.

Penting untuk diketahui, konsep nilai merupakan dasar penyusun RM. Pemasaran dalam kontek relasional dapat dilihat sebagai suatu proses yang harus mendukung penciptaan nilai bagi konsumen. Dengan kata lain, penciptaan nilai merupakan bagian penting dalam suatu interaksi, bukan hanya semata-mata pertukaran produk, atau bagaimana perusahaan berupaya menciptakan nilai tambah bagi konsumennya. Secara sederhana kita dapat mengatakan bahwa perusahaan berupaya menawarkan suatu nilai untuk konsumennya, namun konsumen sendiri yang akan menentukan penilaiannya atas suatu gambaran kepantasan dari sisi ekonomi, teknis, pelayanan, serta manfaat fungsional dan sosial yang diperoleh seorang konsumen pada harga yang dibayarkan. Lebih jauh, setelah penciptaan nilai yang sebelumnya diinisiasi sendiri oleh perusahaan (bersifat seaarah dan cenderung bersifat transaksional), selanjutnya terjadi pergeseran perspektif ke arah value co-creation. Istilah ini mengambarkan suatu proses penciptaan nilai bersama melalui interaksi kreatif di dalam sistem bisnis yang menghasilkan suatu pengalaman nilai, tidak saja bagi konsumen namun juga nilai strategis bagi perusahaan, sehingga kedua belah pihak mendapatkan manfaat dari interaksi yang dilakukan. Kesimpulan dari perspektif value co-creation ini adalah membangun hubungan dengan konsumen untuk memberikan akses kepada perusahaan bagaimana ide atau gagasan penting dan unik yang diperoleh dari interaksinya dengan konsumen dapat meningkatkan daya saing dan inovasi perusahaan.

Sebenarnya berbagai sudut pandang yang digunakan untuk memformulasikan konsep dan implemantasi RM merupakan penguat bagi sudut pandang yang satu dengan yang lainnya. Walaupun diindikasikan saling tumpang tindih, namun ada benang merah yang menghubungkan setiap gagasan. Penulis berpendapat bahwa penciptaan nilai bersama (value co-creation) merupakan perspektif yang paling relevan untuk menguraikan proses dan aktivitas dari konsep relationship marketing pada saat ini. Disisi lain, pemikiran yang berbasis pada RM dalam praktiknya lebih banyak digunakan sebagai landasan utama bagi strategi pemasaran yang dibuat dan dilaksanakan oleh perusahaan. 


\section{DAFTAR PUSTAKA}

Bendapudi, N., \& Leone, R. P. (2003). Psychological Implications of Customer Participation in Co-Production. Journal of Marketing, 67(1), 14-28. https://doi.org/ 10.1509/jmkg.67.1.14.18592.

Berry, L. L. (2002). Relationship Marketing of Services Perspectives from 1983 and 2000. Journal of Relationship Marketing, 1(1), 59-77. https://doi.org/10.1300/ $\underline{\mathrm{J} 366 \mathrm{v} 01 \mathrm{n} 01 \_05}$

Bhalla, G. (2011). Collaboration and Co-creation: New Platforms for Marketing and Innovation (1st ed.). Springer-Verlag New York.

Blois, K. J. (1996). Relationship marketing in organizational markets: When is it appropriate? Journal of Marketing Management, 12(1-3), 161-173. https://doi.org/ $\underline{10.1080 / 0267257 X .1996 .9964406}$

Bröring, S., \& Cloutier, D. (2008). Value-creation in new product development within converging value chains: An analysis in the functional foods and nutraceutical industry. British Food Journal, 110(1), 76-97. https://doi.org/10.1108/00070700810844803

Cambra-Fierro, J., Melero-Polo, I., \& Sese, F. J. (2018). Customer value co-creation over the relationship life cycle. Journal of Service Theory and Practice, 28(3), 336-355. https://doi.org/10.1108/JSTP-01-2017-0009

Carbonell, P., Rodríguez-Escudero, A. I., \& Pujari, D. (2009). Customer Involvement in New Service Development: An Examination of Antecedents and Outcomes*. Journal of Product Innovation Management, 26(5), 536-550. https://doi.org/10.1111/j.1540-5885.2009.00679.x

Christopher, M., Payne, A., \& Ballantyne, D. (1993). Relationship Marketing: Bringing quality, customer service and marketing together. Oxford: ButterworthHeinemann.

Cravens, D., \& Piercy, N. (2012). Strategic Marketing (10 edition). New York: McGraw-Hill Education.

Dwyer, F. R., Schurr, P. H., \& Oh, S. (1987). Developing Buyer-Seller Relationships. Journal of Marketing, 51(2), 11-27. https://doi.org/10.2307/1251126

Egan, J. (2011). Relationship Marketing: Exploring Relational Strategies in Marketing. Financial Times, Prentice Hall.

Erdélyi, P., Ngugi, I. K., \& Johnsen, R. E. (2010). Relational capabilities for value co-creation and innovation in SMEs. Journal of Small Business and Enterprise Development, 17(2), 260-278. https://doi.org/10.1108/14626001011041256 
Forsström, B. (2005). Value co-creation in industrial buyer-seller partnerships - creating and exploiting interdependencies: an empirical case study. Retrieved from http://www.doria.fi/handle/10024/4144

Foster, B. (2008). Manajemen Ritel. Bandung: Alfabeta.

Gronroos, C. (1990). Service Management and Marketing: Managing the Moment of Truth in Service Competition. Lexington, Mass: Lexington Books.

Grönroos, C. (1994). From Marketing Mix to Relationship Marketing: Towards a Paradigm Shift in Marketing. Management Decision, 32(2), 4-20. https://doi.org/10.1108/00251749410054774

Grönroos, C. (1996). Relationship marketing: strategic and tactical implications. Management Decision, 34(3), 5-14. https://doi.org/10.1108/00251749610113613

Grönroos, C. (1997). Value-driven relational marketing: From products to resources and competencies. Journal of Marketing Management, 13(5), 407-419. https://doi.org/10.1080/0267257X.1997.9964482

Grönroos, C. (2000). Creating a Relationship Dialogue: Communication, Interaction and Value. The Marketing Review, 1(1), 5-14. https://doi.org/10.1362/ 1469347002523428

Grönroos, C. (2008). Service logic revisited: who creates value? And who co-creates? European Business Review, 20(4), 298-314. https://doi.org/10.1108/ $\underline{09555340810886585}$

Grönroos, C. (2017). Relationship marketing and service: An update. Journal of Global Scholars of Marketing Science, 27(3), 201-208. https://doi.org/10.1080/21639159.2017.1318666

Gummesson, E. (2008). Total Relationship Marketing, Third Edition: Marketing management, relationship strategy, CRM, and a new dominant logic for the valuecreating network economy (3 edition). London: Butterworth-Heinemann.

Harmeling, C. M., Kumar, V., \& Palmatier, R. W. (2018). Customer engagement marketing. Palgrave Macmillan.

Hunt, S. D. (2010). Marketing Theory: Foundations, Controversy, Strategy, and Resource-advantage Theory. Routledge.

Kotler, P., \& Armstrong, G. (2018). Principles of Marketing. Pearson.

Kotler, P., \& Keller, K. L. (2016). A Framework for Marketing Management (6th, Global Edition). Pearson.

Madhavaram, S., Arnett, D. B., \& Hunt, S. D. (2006). The explanatory foundations of relationship marketing theory. Journal of Business \& Industrial Marketing, 21(2), 72-87. https://doi.org/10.1108/10610420610651296 
Morgan, R. M., \& Hunt, S. D. (1999). Relationship-Based Competitive Advantage: The Role of Relationship Marketing in Marketing Strategy. Journal of Business Research, 46(3), 281-290. https://doi.org/10.1016/S0148-2963(98)00035-6

Morgan, R. M., \& Hunt, S. D. (1994). The Commitment-Trust Theory of Relationship Marketing. Journal of Marketing, 58(3), 20-38. https://doi.org/10.2307/1252308

Normann, R., \& Ramírez, R. (1993). From value chain to value constellation: designing interactive strategy. Harvard Business Review, 71(4), 65-77.

OHern, M. S., \& Rindfleisch, A. (2010). Customer Co-Creation. In N. K. Malhotra (Ed.), Review of Marketing Research (Vol. 6, pp. 84-106). Emerald Group Publishing Limited. https://doi.org/10.1108/S1548-6435(2009)0000006008

Palmatier, R. W. (2008). Relationship Marketing. Cambridge, Mass: Marketing Science Institute.

Palmatier, R. W., Jarvis, C. B., Bechkoff, J. R., \& Kardes, F. R. (2009). The Role of Customer Gratitude in Relationship Marketing. Journal of Marketing, 73(5), 118. https://doi.org/10.1509/jmkg.73.5.1

Palmatier, R. W., Kumar, V., \& Harmeling, M. C. (Eds.). (2018). Customer engagement marketing. Palgrave Macmillan.

Palmer, A. J. (1995). Relationship marketing: Local implementation of a universal concept. International Business Review, 4(4), 471-481. https://doi.org/10.1016/ $\underline{0969-5931(95) 00027-5}$

Palmer, A. J., \& Koenig-Lewis, N. (2009). An entended, community focused, experiential framework for relationship marketing. Journal of Customer Behaviour, 8(1), 85-96. https://doi.org/10.1362/147539209X414407

Petrof, J. V. (1997). Relationship marketing: the wheel reinvented? Business Horizons, 40(6), 26-31. https://doi.org/10.1016/S0007-6813(97)90064-1

Prahalad, C. K., \& Ramaswamy, V. (2004). The Future of Competition: Co-Creating Unique Value with Customers. Harvard Business School Press. Retrieved from https://hbr.org/product/the-future-of-competition-co-creating-unique-value-withcustomers/9535E-KND-ENG

Qi, L., Wang, K., Wang, X., \& Zhang, F. (2010). Research On The Relationship Among Market Orientation, Customer Relationship Management, Customer Knowledge Management And Business Performance. Management Science and Engineering, 2(1), 32-38. https://doi.org/10.3968/j.mse.1913035X20080201.004

Ramaswamy, V. (2008). Co-creating value through customers' experiences: the Nike case. Strategy \& Leadership, 36(5), 9-14. https://doi.org/10.1108/ 10878570810902068 
Rashid, T. (2003). Relationship marketing: case studies of personal experiences of eating out. British Food Journal, 105(10), 742-750. https://doi.org/10.1108/00070700310506281

Ravald, A., \& Grönroos, C. (1996). The value concept and relationship marketing. European Journal of Marketing, 30(2), 19-30. https://doi.org/10.1108/03090569610106626

Rich, M. K. (1999). Business Market Management: Understanding, Creating, and Delivering Value. Journal of Business \& Industrial Marketing, 14(3), 76-80. https://doi.org/10.1108/jbim.1999.14.3.76.1

Ritter, T., \& Gemuenden, H. (2003). Interorganizational relationships and networks: An overview. Journal of Business Research, 56, 691-697. https://doi.org/ $\underline{10.1016 / \mathrm{S} 0148-2963(01) 00254-5}$

Sacui, V., \& Dumitru, F. (2014). Market-based Assets. Building Value through Marketing Investments. Procedia - Social and Behavioral Sciences, 124, 157-164. https://doi.org/10.1016/j.sbspro.2014.02.472

Sharafizad, J., \& Standing, C. (2017). Determinants of relationship marketing by women small business owners. Journal of Small Business \& Entrepreneurship, 29(4), 271-291. https://doi.org/10.1080/08276331.2017.1325267

Sharma, A., Tzokas, N., Saren, M., \& Kyziridis, P. (1999). Antecedents and Consequences of Relationship Marketing: Insights from Business Service Salespeople. Industrial Marketing Management, 28, 601-611.

Sheth, J. N., \& Parvatiyar, A. (1992). Towards a theory of business alliance formation. Scandinavian International Business Review, 1(3), 71-87. https://doi.org/10.1016/0962-9262(92)90012-U

Sheth, J. N., \& Parvatiyar, A. (1995). The evolution of relationship marketing. International Business Review, 4(4), 397-418. https://doi.org/10.1016/0969$\underline{\text { 5931(95)00018-6 }}$

Sirdeshmukh, D., Singh, J., \& Sabol, B. (2002). Consumer Trust, Value, and Loyalty in Relational Exchanges. Journal of Marketing, 66(1), 15-37. https://doi.org/10.1509/jmkg.66.1.15.18449

Smirnova, M., \& P. Kushch, S. (2006). Understanding the Role of Relational Capabilities in Buyer-Seller Relationships.

Smith, J. B. (1998). Buyer-Seller relationships: Similarity, relationship management, and quality. Psychology \& Marketing, 15(1), 3-21. https://doi.org/10.1002/ (SICI)1520-6793(199801)15:1<3::AID-MAR2>3.0.CO;2-I

Smith, M. (2011). The New Relationship Marketing: How to Build a Large, Loyal, Profitable Network Using the Social Web. Wiley. 
Srivastava, R. K., Shervani, T. A., \& Fahey, L. (1998). Market-Based Assets and Shareholder Value: A Framework for Analysis. Journal of Marketing, 62(1), 218. https://doi.org/10.2307/1251799

Sulhaini, S. (2014). Relationship Marketing. Mataram: UPT. Mataram University Press.

Takala, T., \& Uusitalo, O. (1996). An alternative view of relationship marketing: A framework for ethical analysis. European Journal of Marketing - EUR J MARK, 30, 45-60. https://doi.org/10.1108/03090569610106644

Vargo, S. L., \& Lusch, R. F. (2010). "Relationship" in Transition: An Introduction to the Special Issue on Relationship and Service-Dominant Logic. Journal of Business Market Management, 4(4), 167-168. https://doi.org/10.1007/s12087-010$\underline{0042-4}$

Wehrli, H. P., \& Jüttner, U. (1994). Relationship Marketing from a Value System Perspective. International Journal of Service Industry Management, 5(5), 54-73. https://doi.org/10.1108/09564239410074394

Zhang, J. Z., Watson, G. F., Palmatier, R. W., \& Dant, R. P. (2016). Dynamic Relationship Marketing. Journal of Marketing, 80(5), 53-75. https://doi.org/ $\underline{10.1509 / \mathrm{jm} .15 .0066}$

$62 \mid$ Telaah konseptual relationship marketing dan Perkembangannya... 